\title{
Occurrence of Extended Spectrum Beta-Lactamases among Bacterial Isolates from Meat Products Sold within Kaduna Metropolis, Nigeria
}

\author{
M. Yusha'u and M. I. Umar
}

\begin{abstract}
Two hundred (200) meat products including 50 samples each of four different products (Bulangu, Danbun nama, Kilishi and Tsire) sold in Kaduna metropolis were processed for bacterial isolation amongst which 128 Gram negative bacteria were isolated. These include; Escherichia coli 41, Klebsiella pneumoniae 21, Salmonella typhi 18, Serratia mercescens 07, Citrobacter fruendii 17 and Proteus vulgaris 24 were subjected to screening for ESBL production using the standard procedure of Clinical and Laboratory Standards Institute (CLSI). Organisms that were positive for ESBLs were further subjected to confirmation using Double Disc Synergy Test (DDST). The results of ESBLs screening revealed that 38 bacterial isolates were positive for the production of the enzyme. Amongst the 38 CLSI test positive isolates that were subjected to confirmatory test for ESBL production, 19 were confirmed ESBL producers representing $14.84 \%$ of the total isolates from the meat products sampled. However, there exist no significant differences (at $\mathrm{P}=0.05$ ) between the rate of occurrence of the isolates in the different meat products as well as between the isolates on the occurrence of ESBLs when the results were analyzed using two-way and one-way analysis of variance. The occurrence of bacterial isolates in ready to eat meat products coupled with their ability to produce ESBLs is of great public health concern.
\end{abstract}

Keywords-Bacterial isolates, Extended Spectrum Betalactamases, Meat products, Occurrence

\section{INTRODUCTION}

Meat products are obtained when raw or preserved meat are altered in form by grinding, pressing, drying and other processes then augmented in flavor by smoking spicing or blending with other food. These meat products are subjected to combination of several basic processing steps before reaching their final form. There exist different types of meat products ranging from industrially processed ready to eat meat such as balangu (roasted meat), killishi, tsire, dambun nama (shredded form)

Microorganisms that occur in meat and meat products most times are responsible for food borne illness. The source of enterobacteriaceae on meats was shown to be associated with the meat handling and work surfaces at the packing plants and retail facilities. Escherichia coli biotype I and Serratia liquefaciens

Manuscript received March 28, 2016. This work was supported in part by the management of Bayero University, Kano, Nigeria.

M. Yusha'u is with the Department of Microbiology, Bayero University, PMB 3011 Kano, Nigeria.

M. I. Umar was with Department of Microbiology, Bayero University, PMB 3011 Kano, Nigeria. were determined at all stages of meat [1].

Extended spectrum beta-lactamase are enzymes that confer resistance to penicillins, third generation caphelosporins and aztreonam and are inhibited by beta-lactams inhibitor. The ESBLs are derivative of the classical TEM- or SHV- type enzymes. These enzymes were at first given the designation IRT for inhibitor-resistant TEM beta-lactamase, however all have subsequently been renamed with numerical TEM designations [2].

The enterobacteriaceae are a large, heterogenous group of Gram-negative rods whose natural habitat is the intestinal tract of humans and animals. Some enteric organisms, e.g. Escherichia coli, are part of the normal flora and incidentally cause disease, while others, the Salmonellae and Shigellae are regularly pathogenic of humans. During the past two decades, the prevalence of ESBL producing Escherichia coli and Klebsiella pneumoniae (ESBL-EK) increased markedly worldwide. This change in resistance has been found to be associated with the use of extended spectrum cephalosporin (third generation cephalosporins). In particular, ceftezidime use has been implicated as a significant factor in the induction of ESBLs and selection of highly resistant Gram negative bacteria [3]. Cafepime, a fourth generation cephalosporin, has been found to be more stable against ESBLs as well as other Beta lactamase and has not been associated with ESBL induction [7].

The aim of this research is to ascertain the occurrence of ESBL production among the enterobacteria in ready to eat meat product sold in Kaduna metropolis.

The research is to be carried out with the following objectives:

(i) Isolation and characterization of coliforms from meat product samples obtained from the study area

(ii) Screening of isolates for ESBL production by CLSI breakpoint using disc diffusion method

(iii) Confirming of ESBL production by DDST method

(iv) Determining the distribution of ESBLs in relation to the different meat products and the different bacterial species isolated.

\section{MATERIALS AND METHODS}

Sample Collection

The samples include bacterial isolates from various types of ready to eat meat product sold within Kaduna metropolis.

Gram Staining

Gram staining was carried out on the isolates to differentiate the

Gram negative from the Gram positive bacteria [5]. 
Biochemical test for characterization of bacteria

Lactose peptone broth fermentation

Twenty four (24) hours culture of different isolate was inoculated onto a lactose peptone broth contained in a bijou bottle using sterile wire loop and incubated for 24hours [5].

Citrate Utilization Test

A mass of $24.28 \mathrm{~g}$ of simon citrate agar was dissolved in one litre of distilled water and sterilized. The agar medium was then inoculated using sterile needle. This was incubated at $37^{\circ} \mathrm{C}$ for 24-48 hours [5].

KliglerIron Agar

The agar slant was streaked and the butt was stabbed with the test organism and incubated at 37degree celcius for 24 hours [5]. Urea utilization test

Twenty four hours culture of each isolates was inoculated onto a slanted urea agar medium by streaking the slant and stabbing the butt [5].

\section{Suballure}

After identifying the enterobacteriacea, the isolates were aseptically subcultured into Brain-Heart Infusion (BHI) Agar and incubated at 37 degree celcius for 24 hours before screening for ESBLS [5].

Standardization of Inoculum

Few colonies of each isolate were dispensed in sterile normal saline to match the 0.5 Mcfarland for sensitivity as described by National Committee of Clinical Laboratory Standard [8].

Antibiotic Agents

The antibiotics agents used are augmentine (30ug), caftazidime (30ug), and caftriazone (30ug) discs(OxoidEngland).

NCCLS Method for ESBLs Screening

The sensitivity of standard inoculum of isolate to ceftriaxone and ceftazidime disks was determined on Mueller-Hinton Agar by placing the disks independent of one another. The zone of inhibition obtained after 24 hours of incubation at $37^{\circ} \mathrm{C}$ were measured using ruler. The measurement obtained will be compared with NCCLS Standard Table [4] which specifies that for potential ESBL producer zone of inhibition should be $<22 \mathrm{~mm}$ for ceftazidime while < 25mmforceftiaxone.[8]

\section{DoubleDiskSynergyTestforESBLConfimation}

DDST was used in testing/confirming ESBLs Production of the various isolates where the standard inoculums was inoculated into freshly prepared solidified Mueller-Hinton Agar by streaking with the aid of sterile swab stick. Antibiotic discs of ceftazidime (to the left of the medium), augmentine at the middle and cetriaxone were placed on the inoculated medium at a distance of $20 \mathrm{~mm}$ apart. This was incubated for 24 hours at $37^{\circ} \mathrm{C}$ to observe resistance or susceptibility of the isolate for ESBI production. Increased zones of inhibition of the cephalosporin discs towards the central augmentine disc signified positive test for ESBL production [8].

\section{RESULTS}

A total of 128 bacterial were isolated from 200 meat product samples including; 31 isolates from tsire, 46 from kilishi, 26 from balangu and 25 from dambun nama samples. These were subjected to biochemical tests and were identified with reference to standard table [5] (Cheesbrough, 2004). They include; Escherichia coli 41 (20.50\%), Klebsiella pneumoniae. 21 (10.50\%), Salmonella typhi. 18 (9.00\%), Serratia mercescens. 07 (3.50\%), Citrobacter fruendii. 17 (8.50\%) and Proteus vulgaris 24 (12.00\%) as shown in Table 1. The highest rate of bacterial isolation was observed in Kilishi samples with $92 \%$ followed by Tsire with $62.00 \%$ while Balangu and Dambun nama showed $52.00 \%$ and $50.00 \%$ respectively.

On subjecting the 128 bacterial isolates from meat products to standard biochemical tests, members of the family enterobacteriaceae were identified including; Escherichia coli, Klebsiella pneumoniae, Citrobacter fruendii, Serratia mercescens, Salmonella typhi and Proteus vulgaris with E. coli having the highest occurrence (Table 1). On subjecting the identified bacterial isolates to ESBLs screening using NCCLS criteria, 38 isolates tested positive accounting for $29.69 \%$ as shown in Table 2. Amongst the 38 isolates subjected to confirmatory test for ESBLs using DDST, 19 isolates were positive indicating the presence of ESBLs at the rate of $14.84 \%$ (Table 3).

\begin{tabular}{|c|c|c|c|c|c|c|c|}
\hline \multirow{2}{*}{$\begin{array}{l}\text { Meat } \\
\text { products }\end{array}$} & \multicolumn{6}{|c|}{ Isolates } & \multirow[t]{2}{*}{ Toti: } \\
\hline & $\begin{array}{l}E \\
\text { colit }\end{array}$ & $\begin{array}{l}\text { Cirro } \\
\text { bacter } \\
\text { frown } \\
\text { diti }\end{array}$ & $\begin{array}{l}\text { KJeb } \\
\text { sella } \\
\text { pneu } \\
\text { moni } \\
\text { se }\end{array}$ & $\begin{array}{l}\text { Prote } \\
\text { us } \\
\text { wiglga } \\
\text { nis }\end{array}$ & $\begin{array}{l}\text { Salun } \\
\text { onell } \\
\text { a } \\
\text { tophi }\end{array}$ & $\begin{array}{l}\text { Senat } \\
\text { a } \\
\text { mavces } \\
\text { cents }\end{array}$ & \\
\hline Balangu & 06 & 04 & 03 & 06 & 05 & 02 & 26 \\
\hline $\begin{array}{l}\text { Dambua } \\
\text { nama }\end{array}$ & 05 & 02 & 06 & 04 & 06 & 02 & 25 \\
\hline Kilishi & 17 & 04 & 07 & $\infty$ & 06 & 03 & 46 \\
\hline Tsire & 13 & 07 & 05 : & 05 & 01 & $\infty$ & 31 \\
\hline Total & 41 & 17 & 21 & 24 & 18 & 07 & 128 \\
\hline
\end{tabular}

TABLE 2: OCCURRENCE OF ESBLS AMONG THE BACTERIAL ISOLATES BASED ON CLSI SCREENING CRITERIA

$\begin{array}{llc}\begin{array}{l}\text { Meat } \\ \text { products }\end{array} & \text { Isolates } & \text { Total }\end{array}$

\begin{tabular}{llllllll} 
& $\begin{array}{l}\text { E. } \\
\text { coli }\end{array}$ & $\begin{array}{l}\text { Citro } \\
\text { bacte } \\
r\end{array}$ & $\begin{array}{l}\text { Klebs } \\
\text { iella } \\
\text { pneu } \\
\text { freun } \\
\text { moni } \\
\text { dii }\end{array}$ & $\begin{array}{l}\text { Pet } \\
\text { eus }\end{array}$ & $\begin{array}{l}\text { Salmo } \\
\text { vella }\end{array}$ & $\begin{array}{l}\text { Serr } \\
\text { typhi }\end{array}$ & $\begin{array}{l}\text { atia } \\
\text { mar } \\
\text { cesc } \\
\text { ens }\end{array}$ \\
& & & & & \\
\hline Balangu & 06 & 04 & 03 & 06 & $05(01)$ & 02 & 26 \\
& $(02)$ & $(01)$ & $(01)$ & $(02)$ & & $(01)$ & $(07)$ \\
Dambun & 05 & 02 & 06 & 04 & $06(01)$ & 02 & 25 \\
nama & $(01)$ & $(00)$ & $(02)$ & $(01)$ & & $(00)$ & $(05)$ \\
Kilishi & 17 & 04 & 07 & 09 & $06(01)$ & 03 & 46 \\
& $(02)$ & $(01)$ & $(02)$ & $(03)$ & & $(02)$ & $(12)$ \\
Tsire & 13 & 07 & 05 & 05 & $01(01)$ & 00 & 31 \\
& $(07)$ & $(02)$ & $(03)$ & $(01)$ & & $(00)$ & $(14)$ \\
Total & 41 & 17 & 21 & 24 & $18(04)$ & 07 & 128 \\
& $(12)$ & $(04)$ & $(08)$ & $(07)$ & & $(03)$ & $(38)$
\end{tabular}


TABLE 3: DISTRIBUTION OF CONFIRMED ESBLS PRODUCING ISOLATES BASED ON DDST

\begin{tabular}{|c|c|c|c|c|c|c|c|}
\hline \multirow{2}{*}{$\begin{array}{l}\text { Meat } \\
\text { products }\end{array}$} & \multicolumn{6}{|c|}{ Isolates } & \multirow[t]{2}{*}{ Total } \\
\hline & $\begin{array}{l}E . \\
\text { coli }\end{array}$ & $\begin{array}{l}\text { Citr } \\
\text { obac } \\
\text { ter } \\
\text { freu } \\
\text { ndii } \\
\end{array}$ & $\begin{array}{l}\text { Klebs } \\
\text { iella } \\
\text { pneu } \\
\text { moni } \\
\text { ae }\end{array}$ & $\begin{array}{l}\text { Prote } \\
\text { us } \\
\text { vulgar } \\
\text { is }\end{array}$ & $\begin{array}{l}\text { Sal } \\
\text { mon } \\
\text { ella } \\
\text { typh } \\
i \\
\end{array}$ & $\begin{array}{l}\text { Serr } \\
\text { atia } \\
\text { mar } \\
\text { cesc } \\
\text { ens }\end{array}$ & \\
\hline Balangu & $\begin{array}{l}02 \\
(01)\end{array}$ & $\begin{array}{l}01 \\
(00)\end{array}$ & $\begin{array}{l}01 \\
(01)\end{array}$ & $\begin{array}{l}02 \\
(01)\end{array}$ & $\begin{array}{l}01 \\
(01)\end{array}$ & $\begin{array}{l}01 \\
(00)\end{array}$ & $\begin{array}{l}08 \\
(06)\end{array}$ \\
\hline $\begin{array}{l}\text { Dambun } \\
\text { nama }\end{array}$ & $\begin{array}{l}01 \\
(01)\end{array}$ & $\begin{array}{l}00 \\
(00)\end{array}$ & $\begin{array}{l}02 \\
(01)\end{array}$ & $\begin{array}{l}01 \\
(00)\end{array}$ & $\begin{array}{l}01 \\
(01)\end{array}$ & $\begin{array}{l}00 \\
(00)\end{array}$ & $\begin{array}{l}05 \\
(03)\end{array}$ \\
\hline Kilishi & $\begin{array}{l}02 \\
(01)\end{array}$ & $\begin{array}{l}01 \\
(01)\end{array}$ & $\begin{array}{l}02 \\
(00)\end{array}$ & $\begin{array}{l}03 \\
(02)\end{array}$ & $\begin{array}{l}01 \\
(00)\end{array}$ & $\begin{array}{l}02 \\
(01)\end{array}$ & $\begin{array}{l}11 \\
(04)\end{array}$ \\
\hline Tsire & $\begin{array}{l}07 \\
(04)\end{array}$ & $\begin{array}{l}02 \\
(01)\end{array}$ & $\begin{array}{l}03 \\
(01)\end{array}$ & $\begin{array}{l}01 \\
(01)\end{array}$ & $\begin{array}{l}01 \\
(00)\end{array}$ & $\begin{array}{l}00 \\
(00)\end{array}$ & $\begin{array}{l}14 \\
(06)\end{array}$ \\
\hline Total & $\begin{array}{l}12 \\
(07)\end{array}$ & $\begin{array}{l}04 \\
(02)\end{array}$ & $\begin{array}{l}08 \\
(03)\end{array}$ & $\begin{array}{l}07 \\
(04)\end{array}$ & $\begin{array}{l}04 \\
(02)\end{array}$ & $\begin{array}{l}03 \\
(01)\end{array}$ & $\begin{array}{l}38 \\
(19)\end{array}$ \\
\hline
\end{tabular}

\section{DISCUSSION}

A high occurrence of coliforms (64\%) was observed among the meat product samples analyzed which indicates bad hygienic practices either in terms of cleanliness of the equipment used in processing such products or that of the processing personnel as reported by [6].

Of the total 128 identified bacterial isolates that were subjected to ESBLs screening using CLSI breakpoint, 38 isolates tested positive. They include; 12 of the 41 isolates of $E$. coli, 8 out of 21 isolates of Klebsiella pneumoniae., 4 out of 18 Salmonella typhi., 3 out of 07 Serratia mercescens., 4 out of 17 isolates of Citrobacter fruendii. and 7 out of 24 Proteus vulgaris. isolates. These account for ESBLs occurring among the isolates at the rate of $29.69 \%$ (Table 2).

Amongst the 38 ESBLs screening positive isolates subjected to confirmatory test for ESBLs production using double disk synergy test (DDST) method, 19 isolates were positive for ESBLs which account for of $14.84 \%$ of the total isolates (Table 3). They include; E. coli 7, Klebsiella pneumoniae 3, Salmonella typhi. 2, Serratia mercescens. 1, Citrobacter fruendii. 2 and Proteus vulgaris. 4 with E. coli having the highest rate of ESBLs production with $17.07 \%$ while the least occurrence was observed in Salmonella typhi with $11.11 \%$.

In relation to the meat products, ESBLs producing bacteria occur at higher rate in Balangu with 23.08\% followed by Tsire with 19.35 and Dambun nama with $12.00 \%$ while the least occurrence was observed in Kilishi $8.70 \%$. Although there exist no significant difference in occurrence of ESBLs between the meat products as well as between the isolates when the results were compared using Analysis of Variance (ANOVA).

\section{CONCLUSION}

From the results obtained in this study, it can be concluded that the occurrence rate of ESBLs producing isolates from meat products for human consumption is quite alarming.

It is therefore recommended that; (i) The product sellers should be enlightened on the need $\mathrm{f}$ or improved hygiene of equipment used in processing a $\mathrm{s}$ well as that of the handlers themselves.

(ii) Training of those involved on various aseptic technique $\mathrm{s}$ during processing and handling of the products.

(iii) There is the need to regulate the meat products selling outlets within the metropolis for easy monitoring.

\section{REFERENCES}

[1] M. R. Adams and M.O. Moss "Food Microbiology" The Royal Society of Chemistry. Thomas Graham house. Service park, Cambridge, UK. 1999. Pp192-202.

[2] P. A. Bradford "Extended spectum beta lactamases in the $21^{\$}$ Century. Characterisation, epidemiology and detection of this important resistance threat." Joumal of clinical microbiology rev. 48.933-51.2001.

[3] C. Bruin-buisson, P. Legrand, A. Phillipon, G. M. Montraver and J. Duva "Transeferable enzymatic resistance to third generation cephalosporins during nosocomial outbreaks of multi resistant klebsiella pneumonia" Llancet 2; 302-6. 1987.

http://dx.doi.org/10.1016/S0140-6736(87)90891-9

[4] CDC "Laboratory detection of Extended spectrum beta - lactamases (ESBLS) centre for disease control and prevention" 2006.

[5] M. Cheesbrough "District laboratory practice in tropical countries" part 2. Cambridge university press, UK. 2005. Pp38, 65,70,395. http://dx.doi.org/10.1017/CBO9780511581304

[6] I. Gibbons, A. Adesiyun, N. Seepersasingh, and S. Rahman "Investigation for possible source(s) of contamination of read to eat meat products with listeria spp and other pathogens in a meat processing plants" Trinidad. Intl journal of food microbiology 23;359-66. 2006. http://dx.doi.org/10.1016/j.fm.2005.05.008

[7] M. M. Mustafa, L. Carlson, I. Tkaczwak, G. M. Mccracken and G.R. Buchanen "Comparative study of cefepime versus ceftazidime in the empiric of pediatric cancer patients with fever and neutropime" Journal of pediatric infectious diseases. 20(3); 362-9. 2001.

[8] National Committee for Clinical Laboratory Standard (NCCLS). Performance Standards for Antimicrobial Susceptibility Testing. $15^{\text {th }}$ Informational Supplement (M-100-S15), 2005. National Committee for Clinical Laboratory Standard. Wayne, P.A.

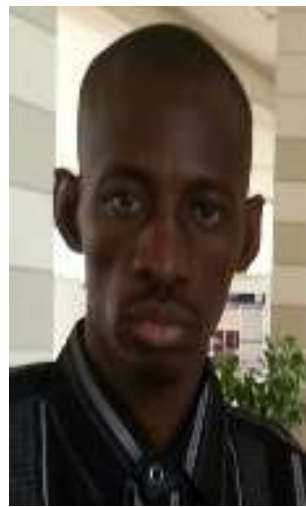

Muhammad Yusha'u was born at Kanya Babba, Babura L. G. A., Jigawa state, Nigeria on the $10^{\text {th }}$ April, 1973). He obtained B. Sc. Microbiology, Bayero University, Kano, Nigeria, 1999. M. Sc. Medical Microbiology, Bayero University, Kano, Nigeria, 2005. PhD Medical Microbiology, Bayero University, Kano, Nigeria, 2009. Antibiotic resistance and drugs development.

He started as Graduate Assistant, Assistant Lecturer, Lecturer II, Lecturer I and currently a SENIOR LECTURER at the Department of Microbiology, Bayero University Kano, Nigeria. He did his one year sabbatical in 2015 at the Department of Microbiology, Kaduna State University. He published many journal articles and books including; Prevalence of Extended Spectrum Betalactamases among Clinical Enterobacteriaceae Isolates obtained from Private Diagnostic Laboratory in Kano - Nigeria, International Journal of Biological and Chemical Sciences, 2011, 5 (1): 365-370. Comparing Ebola virus disease and antimicrobial resistance outbreaks in Nigeria - a cross sectional survey of awareness level of health care workers and members of community, Antimicrobial resistance and infection control, 2015, 4 (Suppl 1): P1. Basic Microbiology, Ibadan, Oyo: Benchmark Publishers, 2010. Basic parasitology, Zaria, Kaduna, ABU Press Ltd., 2016. Areas of research interests are antibiotic resistance and drugs discovery.

Dr. Yusha'u is an editorial board member of Biological and Environmental Science Journal for the Tropics (BEST). 